\title{
Biocontrol of Root-Knot Nematodes through PGPR
}

\author{
Sonam Antil* and Rakesh Kumar \\ Department of Microbiology, College of Basic Sciences and Humanities, \\ CCS HAU, Hisar, Haryana 125004, India \\ *Corresponding author
}

Keywords

Plant growth, Root knot-nematodes, Rhizospheric bacteria

Article Info

Accepted:

07 October 2019

Available Online:

10 November 2019

\section{A B S T R A C T}

Root-knot nematodes are microscopic roundworms that feed on plants and cause damage to them. Nematode damage causes a reduction in plant health and growth which results in decline in quality, yield and decreased resistance to biotic and abiotic stresses. Total crop loss also occurs if there is high level of damage caused by the infection. The continuous application of these nematicides not only affects human health but also have an adverse effect on the productivity, soil texture and nutritional content of the vegetable. Due to the various hazards associated with the use of chemically synthesised nematicides, management of the root-knot nematodes via biological methods is a novel technology emerging for sustainable agriculture. In this context, the plant growth-promoting rhizospheric bacteria (PGPR) are the safe, eco-friendly and most effective alternatives for the management of the disease and the pathogens associated with the disease. This review encapsulates various antagonistic strategies opted by PGPRs against root-knot nematodes.

\section{Introduction}

The most frequently reported and damagecausing nematodes through its plant-parasitic interactions in crops are root-knot nematodes (Meloidogyne spp.) (Collange et al., 2011) which are actively involved in impairing root function by acting as nutrient sinks thus plummeting the crop yield (Luc et al., 2005, Timper et al., 2012). Root-knot nematodes not only deteriorate the crop yield directly but also affect the crop indirectly by increasing the probability of bacterial and fungal pathogens on the crop (Greco et al., 2009). With a growing dominance of nematodes in India, Meloidogyne javanica is considered as an important limiting factor in a yield reduction of brinjal crop. The conventional methods used for controlling plant-parasitic nematodes in agricultural systems are currently dependent 
on use of chemicals which are posing various threats related to environment and are responsible for various health hazards. Therefore, the use of chemicals has been condensed in a significant manner in the past few years which necessitate the need for a new and biological substitute for nematode control. Biological control of nematodes is the use of microbial agents such as bacteria and fungi that are nematophagous or antagonistic to nematodes (Jatala, 1986). So, there have been various noteworthy financial and scientific investments concerned to find effective solutions for the control of parasitic nematodes. During the last ten years numerous scientific articles have acquainted with the achievements of successful Meloidogyne control using rhizobacteria (Mendoza et al., 2008; Vetrivelkalai et al., 2010; Majzoob et al., 2012; Bonaterra et al., 2014; Cetintas et al., 2018).

\section{Root-knot nematodes and their harmful effects}

Root-knot nematodes are plant pathogens which attack a wide range of crops and are distributed worldwide. They have over 3000 host species. The common root-knot nematode species which are most abundant and cause maximum damage to vegetable crops include Meloidogyne incognita, $M$. javanica, $M$. arenaria and M. hapla (Maqbool\&Shahina, 2001). The species of the genus Meloidogyne affect plants by causing various physiological and morphological changes within the roots as a result of which both yield and quality get reduced (Khan et al., 2005). The infection results in foraging, root dysfunction and decreased water and nutrient utilization efficiency. In addition to many direct effects, it is also reported that they predispose host plants to many fungal and bacterial pathogens and make the plant more susceptible to a viral infection which also results in additional yield losses (Norling, 2012).

\section{Plant growth-promoting rhizospheric bacteria (PGPR)}

Plant growth-promoting rhizospheric bacteria help in increasing crop yield by their plant growth-promoting traits and also by producing certain bioactive substances around the root area which contribute significantly towards the suppression of various pathogens by different mechanisms.

\section{Antagonistic mechanisms opted by PGPR}

The application of microorganisms to control plant diseases, which is a form of biological control, is an environment-friendly approach. The chief modes of biocontrol activity of PGPR are competition for nutrients, induced systemic resistance, production of antifungal metabolites and niche exclusion (Lugtenberg and Kamilova, 2009). PGPR promote plant growth indirectly by acting as biocontrol agents (Glick, 2012). PGPR produce a variety of substances which adversely affect the growth of plant pathogens.

\section{Siderophore production}

Iron $(\mathrm{Fe})$ is among the abundant minerals present on the surface of the Earth and is a vital nutrient for all the life forms. Despite its relative abundance, it is unavailable in the soil for plants. Under aerobic environment, Iron is present principally as $\mathrm{Fe}^{3+}$ and is likely to form insoluble hydroxides and oxyhydroxides thus making it generally inaccessible to both plants and microorganisms (Rajkumar et al., 2010). To overcome this problem, PGPR is reported to secrete some extracellular metabolites called siderophores.

Siderophores are low molecular weight ironbinding protein compounds involved in the process of chelating ferric iron from the environment. Kloepper et al., (1980) for the first time reported the significance of 
siderophores produced by certain genera of PGPR in the growth promotion of plants.

The siderophore producing PGPR increase the rate of $\mathrm{Fe}^{3+}$ supply to plants and enhance the growth and productivity of crops. Further, this compound after chelating $\mathrm{Fe}^{3+}$ from the soil makes the soil deficient of $\mathrm{Fe}^{3+}$ and makes the pathogens devoid of this important element (Raaijmakers et al., 2002).

Rhizospheric strains of Pseudomonas, Azotobacter and Bacillus are capable of producing siderophores which act as biocontrol agent and efficiently inhibit phytopathogens like Fusarium sp., Alternaria sp. and Sclerotium sp. (Jenifer et al., 2013)

\section{HCN production}

HCN is the secondary metabolite produced by several microorganisms. It is formed during the early stationary growth phase and has deleterious effects on the growth of some microbes. Some rhizospheric microorganisms have been shown to protect their host plants by inhibiting the growth of plant pathogens through HCN production. Cyanide is a phytotoxic agent that has ability to inhibit enzymes involves in various metabolic processes and is considered as one of the deleterious metabolites in rhizobacterial isolates (Bakker and Schippers, 1987). It does not takes part in growth, energy storage or primary metabolism but has an ecological role and confers a special advantage on the producer strains (Vining, 1990).

Rhizospheric bacteria producing cyanide are host specific and associated with roots of their host plants. Hence, HCN production by these bacteria is a potent and eco-friendly mechanism for biocontrol of weeds and minimizes deleterious effects on desired plant growth (Kremer and Souissi, 2001). Pseudomonas chlororaphis $\mathrm{O} 6$ produces $\mathrm{HCN}$ which shows nematicidal activity against $M$. hapla (Kang et al., 2018).

\section{Production of cell wall degrading enzymes}

Chitin is the second most abundant polymer present in nature next to cellulose. It is found in many organisms like shells, gut linings and exoskeletons of arthropods, cell walls of many fungi and makes up the structural frameworks of certain protists as well as of the eggs of nematodes.

The microbial genome contains genes encoding chitinolytic enzymes which weaken and degrade the cell walls of many pathogens and pests thereby exhibiting antifungal, antibacterial, insecticidal and nematicidal activities (Edreva, 2005). The production and secretion of certain wall degrading enzymes is yet another indirect mechanism of plant growth promotion by PGPR.

These enzymes disturb the structural integrity of cell wall of plant pathogens (Budi et al., 2000). These wall degrading enzymes mainly include cellulase, chitinase, protease and $\beta-1$, 3 -glucanase. These enzymes have direct inhibitory effect on hyphal growth of fungal pathogens and $\beta-1,3$-glucanase and chitinase degrade chitin which is the main component of cell wall of pathogens (Labuschagne et al., 2010).

The mechanism of chitin hydrolysis starts with cleaving the polymer into water-soluble oligomers by one enzyme (Endo-acting chitinase, EC 3.2.1.14) and then cleavage of oligomers into dimers and monomers by another enzyme (Exo-acting $\beta-\mathrm{N}$ acetylhexosaminidase). Another alternative pathway for chitin hydrolysis is deacetylation of chitin to chitosan which is then broken into low molecular weight glucosamine residues by chitosanase (EC 3.2.1.132) which are easier to degrade. Bacillus thuringiensis shows 
antifungal activity against Verticillium sp. (Hollensteiner et al., 2017)

\section{Future Perspective}

Biological control of diseases and pathogens is initially expensive as lots of money and planning goes in setting up a biological control system. But it can become costeffective for the long run as the biocontrol agents can maintain themselves in the environment due to their self perpetuating nature. In the last two decades many companies have formulated and commercialized some microbial biocontrol agents with proven efficacy.

But there is still scope for a variety of other microbial antagonists that are still untested or are in advance stages of research. The research should be emphasized on investigating mechanism of action of biocontrol agents, the signalling pathways that induce plant host defence mechanism so that expression of enzymes and toxins can be increased that would aid in formulation and commercial production of the effective biopesticides

\section{Summary}

PGPR act as biocontrol agents via various means. The mechanism of disease control through these biocontrol agents commonly rely on the competition for space and nutrients, metabolite production, signalling molecules manipulation. The bacteria degrade pathogens by secreting certain compounds like siderophores which sequester iron and make the pathogen devoid of this element, $\mathrm{HCN}$, toxins, surface-active compounds also known as biosurfactants which cause difficulty in survival of the pathogens.

Certain wall degrading enzymes like cellulase, chitinase come under important mechanisms by which they control the pathogens. These enzymes degrade structural integrity of cell wall of the pathogens.

\section{References}

Bonaterra, A., Badosa, E., Rezzonico, F., Duffy B. and Montesino, E. (2014) Phenotypic comparison of clinical and plant-beneficial strains of Pantoea agglomerans. Int. Microbiol., 17, 81-90.

Cetintas, R., Kusek, M. and Fateh, S. A. (2018) Effect of some plant growth-promoting rhizobacteria strains on root-knot nematode, Meloidogyne incognita, on tomatoes. Egypt. J. Biol. Pest Control, 28, 7.

Collange, B., Navarrete, M., Peyre, G., Mateille, T. and Tchamitchian, M. (2011) Rootknot nematode (Meloidogyne) management in vegetable crop production: the challenge of an agronomic system analysis. Crop Prot., 30, 1251-1262.

Greco, N. and Di Vito, M. (2009) Population dynamics and damage levels.Root-knot Nematodes, Pp. 246-274.

Jatala P. (1986) Biological control of plant parasitic nematodes. Annu. Rev. Phytopathol., 24, 453-489.

Khan, H.U., Mukhtar, T. and Ahmed, R. (2005) Geographical distribution of root-knot nematodes (Meloidogyne sp.) in the Punjab Province of Pakistan. Pak. J. Nematol, 23, 133-140.

Luc, M., Sikora, R.A. and Bridge, J. (2005) Plant parasitic nematodes in tropical and subtropical agriculture. $\mathrm{CAB}$ Int., 2, Wallingford, Oxford, UK.

Maqbool, M.A. and Shahina, F. (2001) Biodiversity of nematode fauna in Pakistan. National Nematological Research Centre, University of Karachi, Karachi, 179.

Majzoob, S., Karegar, A., Taghavi, M. and Hamzehzarghani, H. (2012) Evaluation of rhizobacteria for antagonistic activity against root-knot nematode, Meloidogynejavanicaon cucumber, under greenhouse condition. Iran. J. Plant Pathol.,48(1), 27-29.

Mendoza, A.R, Kiewnick, S. and Sikora, R. (2008) In vitro activity of Bacillus firmus against the burrowing nematode Radopholus similis, the root-knot nematode Meloidogyne 
incognita and the stem nematode Ditylenchus dipsaci. Biol. Sci. Technol., 18(4), 377-389.

Norling, J.W. (2012) Nematode management in tomatoes, peppers and eggplant. ENY-032, Entomology and Nematology Department, Florida Cooperative Extension Service, Institute of Food and Agricultural Sciences, University of Florida, 1-15.

Timper, P., Davis, R., Jagdale, G. and Herbert, J. (2012) Resiliency of a nematode community and suppressive service to tillage and nematicide application. Appl. Soil. Ecol., 59, 48-59.

Vetrivelkalai, P., Sivakumar, M. and Jonathan, E.I. (2010) Biocontrol potential of endophytic bacteria on Meloidogyne incognita and its effect on plant growth in bhendi. J. Biopesticides, 3(2), 452-457.

Rajkumar, M., Ae, N., Prasad, M.N.V. and Freitas, H. (2010) Potential of siderophore-producing bacteria for improving heavy metal phytoextraction. Trends Biotechnol.,28, 142-149.

Lugtenberg, B. \&Kamilova, F. (2009) Plantgrowth-promoting rhizobacteria. Annu. Rev. Microbiol., 63, 541-556.

Glick, B.R. (2012) Plant growth-promoting bacteria: mechanisms and applications. Scientifica, 2012, 15.

Raaijmakers, J.M., Vlami, M. and de Souza, J.T. (2002) Antibiotic production by bacterial biocontrol agent. Anton van Leeuwenhoek, 81,537-547.

Jenifer, M.R.A., Reena, A., Aysha, O.S., Valli, S., Nirmala, P. and Kumar, P.V. (2013) Isolation of siderophore producing bacteria from rhzosphere soil and their antagonistic activity against selected fungal plant pathogens. Inter. J. Curr. Microbiol. App. Sci., 2, 59-65.
Kloepper, J.W., Leong, J., Teintze, M. \&Schroth, M.N. (1980) Pseudomonas siderophores: a mechanism explaining disease suppressive soils. Curr.Microbiol.,4, 317-320.

Kremer, R.J. and Souissi, T. (2001) Cyanide production by rhizobacteria and potential suppression of weed seedling growth. Curr Microbial., 43, 182-186.

Kang, B.R., Anderson, A J. and Kim, Y.C. (2018) Hydrogen cyanide produced by Pseudomonas chlororaphis O6 exhibits nematicidal activity against Meloidogyne hapla. Plant Pathol J., 34(1), 35-43.

Bakker, A.W. and Schippers, B. (1987) Microbial cyanide production in the rhizosphere in relation to potato yield reduction and Pseudomonas sp.-mediated plant growth stimulation. Soil Boil Biochem, 19, 451-457.

Budi, S.W., Van, T.D., Arnould, C., DumasGaudot, E., Gianinazzi-Pearson, V. \&Gianinazzi, S. (2000) Hydrolytic enzyme activity of Paenibacillus sp. strain B2 and effects of the antagonistic bacterium on cell integrity of two soil borne pathogenic bacteria.Appl Soil Ecol, 15, 191-199.

Edreva, A. (2005) Pathogenesis-related proteins: research progress in the last 15 years. Gen. Appl Plant Physiol., 31, 105-124.

Labuschagne, N., Pretorius, T. and Idris, A.M. (2010) Plant growth-promoting rhizobacteria as biocontrol agents against soil-borne plant diseases. MicrobiolMonogr., 18, 211-230.

Hollensteiner, J., Wemheuer, F., Harting, R., Kolarzyk, A.M., Valerio, S.M.D., Poehlein, A., Brzuszkiewicz, E.B., Nesemann,K., Braus-Stromeyer, S.A., Braus, G.H., Daniel, R. and Liesegang, H. (2017) Bacillus thuringiensis and Bacillus weihenstephanensis inhibit the growth of phytopathogenic Verticillium species. Front Microbiol., 7, 2171.

\section{How to cite this article:}

Sonam Antil and Rakesh Kumar. 2019. Biocontrol of Root-Knot Nematodes through PGPR. Int.J.Curr.Microbiol.App.Sci. 8(11): 510-514. doi: https://doi.org/10.20546/ijcmas.2019.811.062 